\title{
Demonstration of Improved Variety and Production Technology of Pulses through Cluster Village Approach
}

\author{
K. Venkatalakshmi* \\ Krishi Vigyan Kendra, Virudhachalam, India \\ *Corresponding author
}

\section{A B S T R A C T}

\begin{tabular}{|l|}
\hline Ke y w or d s \\
$\begin{array}{l}\text { Demonstration of } \\
\text { pulses, cluster } \\
\text { village approach, } \\
\text { Improved varieties } \\
\text {,Black gram and } \\
\text { green gram }\end{array}$ \\
\hline Article Info \\
\hline $\begin{array}{l}\text { Accepted: } \\
\text { 12 May 2020 } \\
\text { Available Online: } \\
\text { 10 June } 2020\end{array}$ \\
\hline
\end{tabular}

To ensure participation of the small and marginal farmers in socio-economic development, a unique Village Cluster Development Approach is evolved under NMOOP scheme during the year of 2016-17 by Krishi vigyan Kendra, Vridhachalam. Totally 30 ha of land were utilized for this demonstration. Out of this 20 ha was under black gram and 10 ha was under green. Farm families in cluster of villages were motivated to participate in holistic development through demonstration of high yielding varieties of black gram and green gram varieties, Seed treatment with bio fertilizers and bio control agents, spraying of pulse wonder, and integrated pest management practices. The farmers were also supplied with the critical inputs like seeds, bio fertilizers, bio control agents, pulse wonder, etc. for income generation and for improving the quality of life.This cluster village approach enabled over 95 per cent of black gram farmers and $90 \%$ of the participant green gram farm families socio economic status were improved . The average crop yield increased by $10 \%$ in black gram and 14 per cent in green gram while the overall income increased by 10 per cent for black gram and 37.2 per cent for green gram

\section{Introduction}

Importance of pulses in maintaining food security as well as nutritional security has been felt since long. In India pulses grown on around, 30.5 million hectares area with 20 million tones of production with an average yield of $654 \mathrm{~kg} / \mathrm{ha}$. (IIPR, 2014). In the past few decades, pulses production has not kept up with growth in demand calling import to the tune of 3.0 million tones. The production of pulses definitely needs to be increased manifold to meet the demand in coming years. Farmers grow pulses in the marginal lands with marginal input. But pulses can also be very remunerative.

There is tremendous potential of pulses in both irrigated and rain fed areas. The incorporation of pulses in the existing cropping systems will not only increase the pulses production, but also enrich the soil 
fertility status. The major constraint identified with respect to pulses production Vridhachalam block of Cuddalore district, Tamil Nadu is lack of improved varieties and quality seed, reluctance in adopting the improved practices.

Keeping this in view the cluster village approach has been implemented to give emphasis on adoption of improved varieties of pulses, adopting improved crop management and integrated pest management practices in farmer participatory mode with active involvement of multidisciplinary team of scientist.

Before the intervention the farmers were unaware about the new varieties released regarding black gram and green gram and lack of awareness in following improved pulses production technologies and integrated pest management practices. A pulse farmer realized low production and income.

\section{Materials and Methods}

To ensure participation of the small and marginal farmers in socio-economic development, a unique Village Cluster Development Approach was evolved under NMOOP scheme during the year of 201617.Major pulse growing area is selected to conduct cluster front line demonstration. In Vridhachalam block, Karnatham village, Vessalore village and Kattur parur was selected as a one cluster, M. Agaram was selected as a another cluster village to conduct the cluster front line demonstration in black gram.

For green gram Mankulam village, Mangalore block was selected as cluster village .Totally 50 nos. of demonstration was conducted for black gram and 25 nos. of demonstrations is selected for green gram under rain fed situation. In each cluster 25 nos. of demonstrations were conducted. Small and marginal farmers were selected to conduct the demonstrations. The farmers were also supplied with the critical inputs like seeds, bio fertilizers, bio control agents, pulse wonder, TNAU MN mixture, bird perches and yellow sticky traps. In each clusters the above mentioned varieties and technologies were demonstrated. The black gram and green gram crops were raised during October $2^{\text {nd }}$ fortnight -November $1^{\text {st }}$ fortnight. The crop is raised in both irrigated and partially irrigated conditions. The crops were harvested during January month.

The following improved variety and technologies were demonstrated to the farmers. Demonstration of improved varieties in black gram var. VBN 5 and green gram var.CO8, seed treatment with bio-fertilizers Rhizobium and phosphobacteria, seed treatment with Pseudomonas fluorescens at $10 \mathrm{~g} / \mathrm{kg}$ of seed ,application of TNAU micro nutrient mixture @2 kg/acre, spraying of pulse wonder at flowering stage@ $2 \mathrm{~kg} / \mathrm{acre}$, demonstration of Integrated Pest Management practices, setting of yellow sticky traps and bird perches .

\section{Results and Discussion}

\section{Black gram}

In cluster front line demonstration of black gram, improved variety of VBN 5 along with improved production technologies and IPM were compared with the farmers practice with the variety of VBN 4 . The average lower germination per centage of black gram was recorded 75 in farmers practice and 78 per cent in demo. The average higher number of 33.7 pods /plant was recorded in demo and 28.8 were recorded in check. The average filling per centage of pod was recorded as 75.7 in check and 80.0 recorded in demonstration (Table 1). 
The average yield was recorded as $8.34 \mathrm{q} / \mathrm{ha}$ in demo and $7.51 \mathrm{q} /$ ha in check. There was 10 per cent increase in yield by adopting improved variety, production technologies and IPM strategies. There was average increase of Rs.3711 in net income of the farmer in demonstration over check. The benefit cost ratio was recorded in the demo was 2.3 over the check (2.2). The post-harvest soil fertility status was improved in variably in all the demonstration plots (Table 1).

\section{Green gram}

In cluster front line demonstration of green gram, improved variety of $\mathrm{CO} 8$ along with improved production technologies and IPM were compared with the farmers practice with the variety of $\mathrm{VBN} 3$. Higher average germination percentage 72.0 per cent was recorded in demo than the farmer's practice (65 per cent). More number of pods/plant was recorded in the demonstrations (8.2) than the check (6.3). The average filling per cent of pod was recorded as 70.8 in check and 65.6 recorded in demo (Table 2). More average yield $5.85 \mathrm{q} / \mathrm{ha}$ was recorded in demo than the check $5.05 \mathrm{q} / \mathrm{ha}$. There was 14.0 per cent increase in yield by adopting improved variety, management practices and IPM strategies. More net income of Rs.7005/ha was realized in demo than the farmers practice (Rs.5216/ha). The benefit cost ratio was recorded in the demo was 1.3 over check (1.2). The post-harvest soil fertility status were improved in variably in all the demonstration plots (Table 2).

Farmer's perception, their feedback and horizontal spread of technology

Regarding the improved variety both in black gram and green gram 98 per cent of the farmer's perception was high regarding high yielding nature, moderately resistant variety to yellow mosaic virus resistance and realizing more net income than the earlier variety (Figure 1 and 2). More than 80 per cent of farmer's perception regarding foliar spray of pulse wonder was high to moderate problem solving, practicability, cost effectiveness and profitability (Figure 3 and 4) with respect to black gram and green gram. With regard to IPM for black gram and green gram more than 70 per cent of the farmers perception was moderate to high about the pest control, practicability, profitability and compatibility ((Figure 5 and 6).

Table.1 Cluster Front line demonstrations -Average Germination per centage, yield parameters, yield and economics of black gram comparison between improved varieties and production practices of demo with farmers practice of check

\begin{tabular}{|l|l|l|l|}
\hline S.No & $\begin{array}{l}\text { Particulars } \\
\text { (Average value of all } \\
\text { demonstrations) }\end{array}$ & Check & Demo \\
\hline $\mathbf{1}$ & Germination (\%) & 75.2 & 78.2 \\
\hline $\mathbf{2}$ & No.of pods/plant & 28.8 & 33.7 \\
\hline $\mathbf{3}$ & Pod filling percentage & 75.7 & 80.1 \\
\hline $\mathbf{4}$ & Yield (q/ha) & 7.56 & 8.22 \\
\hline $\mathbf{5}$ & Net return (Rs/ha.) & 32,848 & 36,559 \\
\hline $\mathbf{6}$ & B:C ratio & 2.2 & 2.3 \\
\hline
\end{tabular}


Table. 2 Cluster Front line demonstrations -Average Germination per cent, yield parameters, yield and economics of green gram comparison between improved varieties and production practices of demo with farmers practice of check

\begin{tabular}{|c|c|c|c|}
\hline S.No & $\begin{array}{c}\text { Particulars } \\
\text { (Average value of all the } \\
\text { demonstrations ) }\end{array}$ & Check & Demo \\
\hline $\mathbf{1}$ & Germination (\%) & 65.0 & 72.0 \\
\hline $\mathbf{2}$ & No.of pods/plant & 6.3 & 8.2 \\
\hline $\mathbf{3}$ & Pod filling percentage & 65.6 & 70.8 \\
\hline $\mathbf{4}$ & Yield (q/ha) & 5.05 & 5.85 \\
\hline $\mathbf{5}$ & Net return (Rs/ha.) & 5216 & 7005 \\
\hline $\mathbf{6}$ & B:C ratio & 1.19 & 1.29 \\
\hline
\end{tabular}

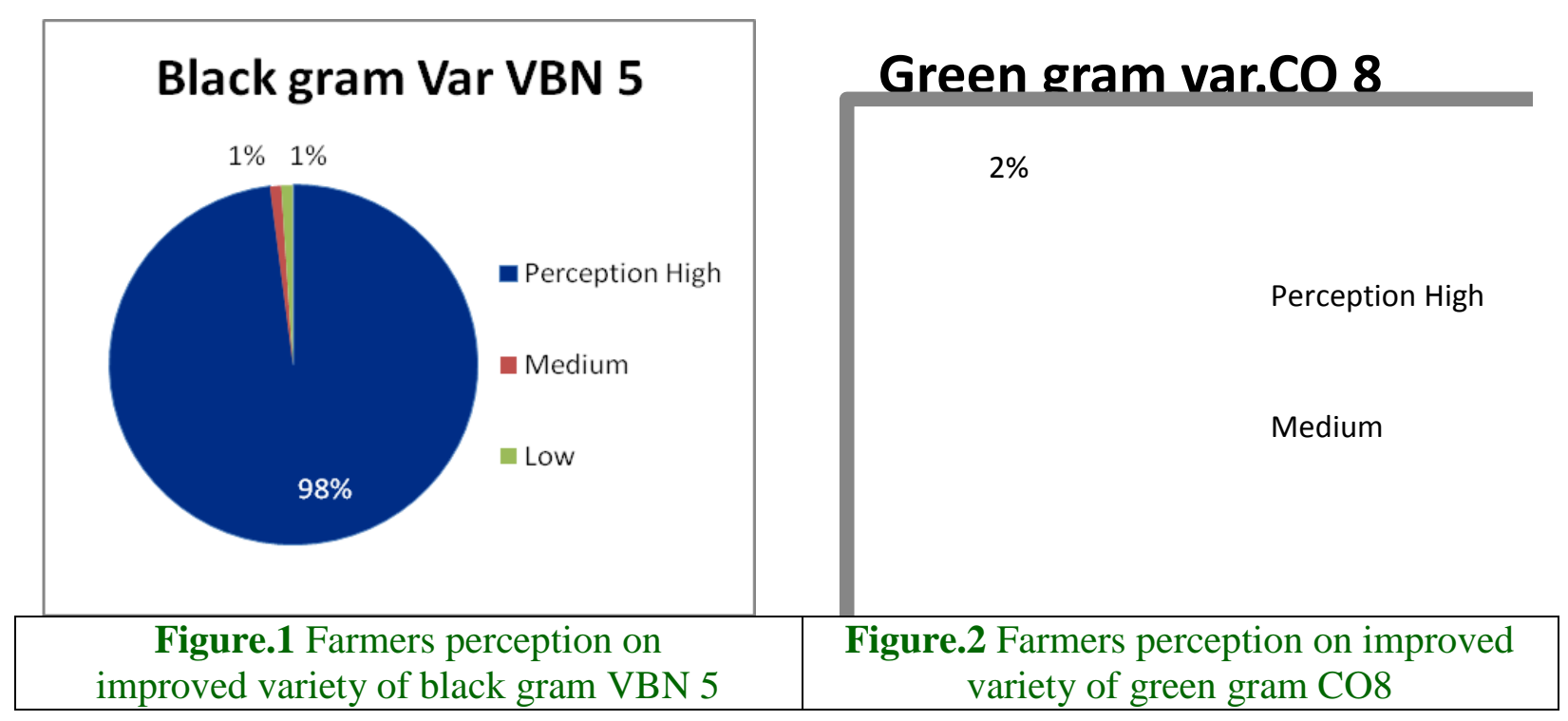

\begin{tabular}{|c|c|}
\hline $\begin{array}{c}\text { Green gram- Pulse wonder } \\
\text { spray }\end{array}$ & Black gram-Pulse wonder \\
spray \\
\hline
\end{tabular}




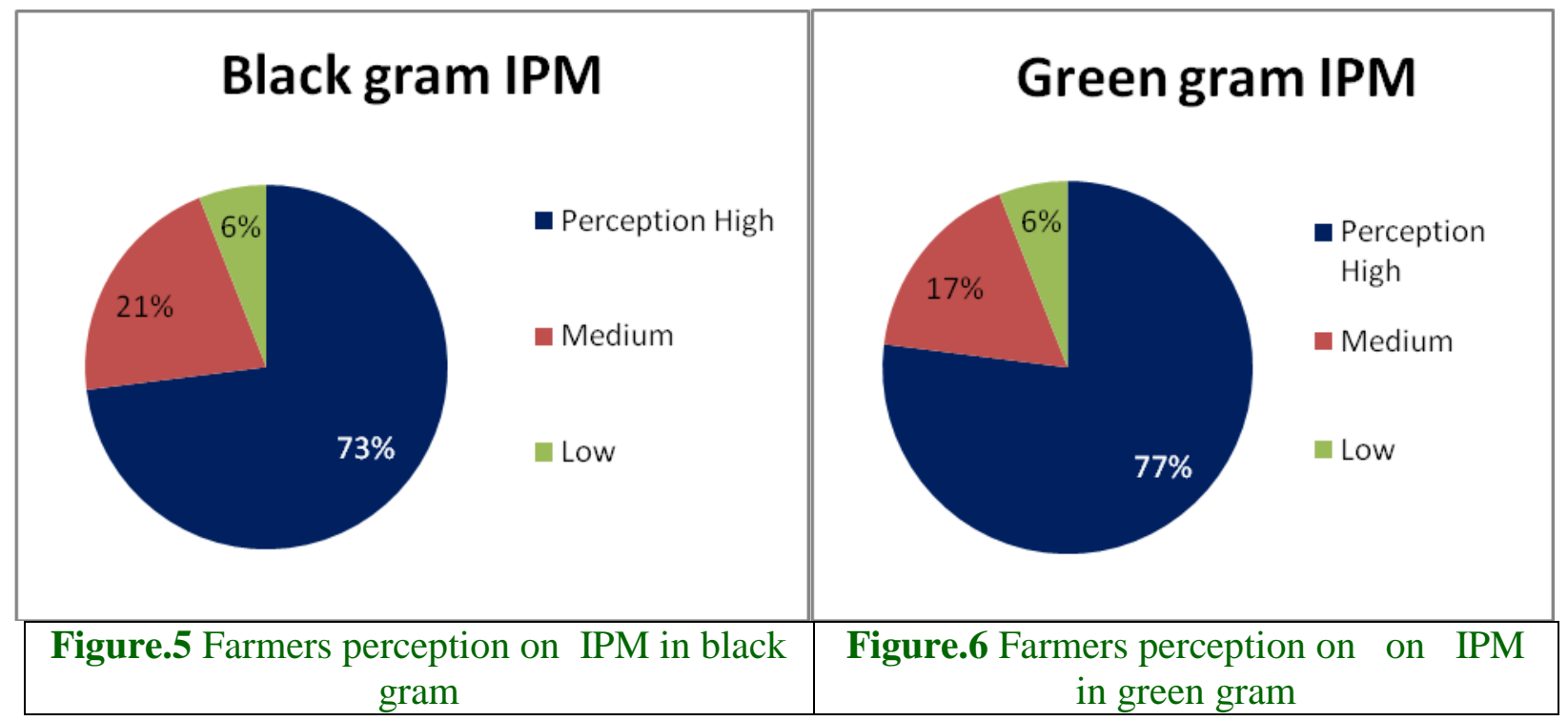

The technologies demonstrated were easy and simple to follow and they are low cost, effective and profitable technologies. The improved varieties both in black gram and green gram were performed better even under scarce rain fall and they are resistant to yellow mosaic virus. The farmers in and around cluster villages want to distribute pulse wonder through Department of Agriculture in coming years. The farmers in the Karnatham, M. Agaram and nearby villages adopted improved variety of black gram var.VBN 5 followed improved production technologies and IPM practices demonstrated around 250 acres of land.

The yield were increased 8.03 per cent for black gram and 13.7 per cent for green gram despite of inadequate rain fall received during the cropping period. Farmers were realized higher net income (10.15 per cent for black gram and 25.5 percent for green gram) than the check. The post-harvest soil fertility statuses of soil were also improved than the initial status of soil. Hence it is concluded that the socio economic status of Karnatham and M. Agaram for black gram farmers and M.
Agaram for green gram farmers were improved respectively. Besides post-harvest soil fertility status were also improved in all the clusters. The cluster village approach holds good for sustainable improvement in pulse production in near future in the above mentioned villages (Usha Tuteja, 2011 and Roy buram et al., 2008).

\section{References}

Roy Burman,R., Singh,S.K, Lakhan Singh \& Singh,A.K.(2008). Extension Strategies for increasing Pulses Production for Evergreen Revolution: Indian Research Journal of Extension. Education. 8 (1): 5-8

http://iipr.res.in/pulse-data-book.html

Usha Tuteja.2011.Ph.D.Thesis: Possibilities and Constraints of increasing Production of Pulses and Impact of National Food Security Mission on Pulses in Haryana. Agricultural Economics Research Centre. University of Delhi, Delhi. 
How to cite this article:

Venkatalakshmi. K. 2020. Demonstration of Improved Variety and Production Technology of Pulses through Cluster Village Approach. Int.J.Curr.Microbiol.App.Sci. 9(06): 98-103. doi: https://doi.org/10.20546/ijcmas.2020.906.012 